\title{
Body changes: antiretroviral therapy and lipodystrophy syndrome in people living with HIV/aids ${ }^{1}$
}

\author{
Luciana Castelar Tsuda ${ }^{2}$ \\ Mariana Machado da Silva² \\ Alcyone Artioli Machado ${ }^{3}$ \\ Ana Paula Morais Fernandes ${ }^{4}$
}

\begin{abstract}
Objective: to identify the different types of morphological alterations from lipodystrophy syndrome (LS) in outpatients and relate them to the therapeutic regimen used. Method: a cross-sectional study which recruited 60 patients with HIV and LS and 79 without LS, who consented to interview and data collection from their medical notes. Results: the region most affected by lipoatrophy was the face; by lipohypertrophy, the abdomen, and by the mixed form, the alterations to the abdomen, face, and upper and lower limbs. Conclusion: among the therapeutic regimens, that comprised of zidovudine, lamivudine and efavirenz seemed to protect against LS. Nursing can act in the early identification of the changes, as well as providing guidance and support for patients affected by the changes in their body image.
\end{abstract}

Descriptors: HIV-1; Antiretroviral Therapy, Highly Active; HIV-Associated Lipodystrophy Syndrome; Nursing.

\footnotetext{
${ }^{1}$ Supported by Fundação de Amparo à Pesquisa do Estado de São Paulo (FAPESP), Brazil, Process \# 06/58476-7.

2 RN, MSc.

${ }^{3} \mathrm{PhD}$, Associate Professor, Faculdade de Medicina de Ribeirão Preto, Universidade de São Paulo, Brazil.

${ }^{4} \mathrm{PhD}$, Associate Professor, Escola de Enfermagem de Ribeirão Preto, Universidade de São Paulo, WHO Collaborating Centre for Nursing Research Development, Brazil.
}

Corresponding Author:

Ana Paula Morais Fernandes

Universidade de São Paulo. Escola de Enfermagem de Ribeirão Preto

Departamento de Enfermagem Geral e Especializada

Av. dos Bandeirantes, 3900

Bairro: Monte Alegre

CEP: 14040-902, Ribeirão Preto, SP, Brasil

E-mail: anapaula@eerp.usp.br 


\title{
Alterações corporais: terapia antirretroviral e síndrome da lipodistrofia em pessoas vivendo com HIV/AIDS
}

Objetivo: identificar os diferentes tipos de alterações morfológicas da síndrome da lipodistrofia (SL) em pacientes dos atendimentos ambulatoriais e relacioná-las ao esquema terapêutico utilizado. Método: estudo transversal, para o qual foram recrutados 60 pacientes com HIV e SL e 79 sem a SL, que consentiram entrevista e coleta de dados em prontuário. Resultados: a região mais acometida pela lipoatrofia foi a face; pela lipo-hipertrofia o abdome e pela forma mista as alterações em abdome, face, membros superiores e inferiores. Conclusão: dentre os esquemas terapêuticos, o composto pela zidovudina, lamivudina e efavirenz pareceu proteger contra a SL. A enfermagem pode atuar na identificação precoce das alterações, além de fornecer orientações e apoio aos pacientes acometidos pelas mudanças na imagem corporal.

Descritores: HIV-1; Terapia Anti-Retroviral de Alta Atividade; Síndrome de Lipodistrofia Associada ao HIV; Enfermagem.

\section{Alteraciones corporales: terapia antirretroviral y síndrome de la lipodistrofia en personas que viven con VIH/SIDA}

\begin{abstract}
Objetivo: identificar los diferentes tipos de alteraciones morfológicas del Síndrome de la lipodistrofia (SL) en pacientes de los servicios de ambulatorio y relacionarlas al esquema terapéutico utilizado. Método: estudio transversal en lo que fueron reclutados 60 pacientes con VIH y la SL y 79 sin la SL, que consintieron entrevista y recogida de datos en prontuario. Resultados: la región más acometida por la lipoatrofia fue la cara; por la lipohipertrofia el Abdomen y por la forma mixta las alteraciones en Abdomen, cara, miembros superiores e inferiores. Conclusión: entre los esquemas terapéuticos, el compuesto por la zidovudina, lamivudina y efavirenz pareció proteger contra la SL. La enfermería puede actuar en la identificación precoz de las alteraciones, además de suministrar orientaciones y apoyo a los pacientes acometidos por los cambios en la imagen corporal.
\end{abstract}

Descriptores: VIH-1; Terapia Antirretroviral Altamente Activa; Síndrome de Lipodistrofia Asociada a VIH; Enfermería.

\section{Introduction}

Lipodystrophy Syndrome (LS) is currently one of the most worrying problems resulting from antiretroviral therapy (ARVT) for combatting the human immunodeficiency virus (HIV). Its pathogenicity still not totally understood, it is observed in therapeutic regimens which include the antiretrovirals (ARV) in the classes of the Nucleoside Analog Reverse-Transcriptase Inhibitors (NARTI) and the Protease Inhibitors (PI) (1-2).

It is characterized principally by alterations in the distribution of body fat, such as the loss of peripheral subcutaneous tissue and increase of central fat, and by metabolic disorders such as dyslipidemia, insulin resistance and abnormal glucose homeostasis, which may contribute to the development of cardiovascular illnesses and diabetes mellitus ${ }^{(3-4)}$.

Morphological abnormalities resulting from alterations in the distribution of fat are manifested in various ways. Lipoatrophy (loss of adipose tissue) is noted on the face, buttocks and limbs, in which the venous circulation becomes more evident. Fat accumulation (lipohypertrophy) is seen in the central abdominal region, in addition to deposits in the breasts and dorsocervical region, also called the "buffalo's hump"(5-6).

Fat loss and accumulation can occur simultaneously - in different regions of the body - in the same individual. 
This is called the mixed form. About $50 \%$ of the patients receiving antiretroviral therapy are affected by body changes resulting from $\mathrm{LS}^{(7-8)}$. Among Brazilian patients, the prevalence described was of $55 \%{ }^{(9)}$. Despite the great success of drug therapy in reducing the patients' morbidity and mortality rates ${ }^{(10)}$, the effects of LS - in particular, those which cause alterations in body image - contribute to the appearance of stigma, problems in social activities and alterations in sexuality, among others, impacting on quality of life $\mathrm{e}^{(11-12)}$.

Nursing has been developing various studies concerning the effects of LS on patients, from identifying their perceptions about changes in appearance ${ }^{(13)}$, to testing interventions which help them to face these ${ }^{(14)}$. The periodicals in the area, however, do not provide detailed evidence on discriminating between the morphological abnormalities by anatomical region, correlated with the ARVT used. Providing nursing care for the HIV patient requires varying skills of health professionals, as they are dealing with a client group which presents a range of simultaneous needs. Particularly in relation to drug therapy, the nurse has the mission of informing the client about its benefits and the need for good compliance, as well as the possible side-effects and ways of controlling them, such that the patient feels safe in undergoing the treatment $^{(15)}$.

Thus, this study aimed to identify the different types of morphological alterations from LS present in outpatients and relate them to the therapeutic regimen being used, so as to provide support for nursing professionals to be able to promote specialized care for this population's needs.

\section{Method}

This is a cross-sectional, comparative, descriptive study, carried out through a questionnaire with 14 closed questions, which included demographic data, current conditions of opportunistic infection, the case history of the HIV infection, ARV medication being used, and clinic-laboratory and somatometric data. The questionnaire was developed by the study group, based on the literature available, and applied by the same group individually to each patient, before or after their routine medical consultation, in a private room. Laboratory data, as well as data of the ARV therapeutic regimens, were taken from the patients' medical notes. The study was approved by the Research Ethics Committee of the Clinical Hospital of the Faculty of Medicine of Ribeirão Preto (process no 5761/2007) and all the participants signed the Terms of Free and Informed Consent.

\section{Study population}

Sixty patients with LS were selected at the Dyslipidemia Outpatient Department in the Special Unit for Treatment of Infectious Diseases at the Clinical Hospital of the Faculty of Medicine of Ribeirão Preto, part of the University of São Paulo, which exclusively attends patients with HIV-1, and is a regional center of excellence for this type of care. The study's inclusion criteria were: positive serology for HIV-1, age between 18 and 65 years, treatment with ARV for a minimum of 18 months and morphological alterations related to LS. The morphological alterations of the patients with LS were identified based on agreement between the patients' accounts, medical observations, and observations made by the researchers about body shape alterations.

For the comparison group, the researchers selected 79 patients with positive serology for HIV-1, aged between 18 and 65, receiving ARV treatment for a minimum of 18 months and with no reference for any type of body change related to LS.

\section{Statistical analysis}

The results were analyzed using Fisher's exact test, with the help of the GraphPad InStat 3.01 program. Associations with a probability of below $5 \%(p<0.05)$ were considered.

\section{Results}

Of the 60 patients with LS selected for the study, $40(67 \%)$ were male and 20 (33\%) female; 45 (75\%) were Caucasian, 08 (13.33\%) were Afro-Brazilian and $7(11.66 \%)$ were mixed-race. The participants' average age was $43.08 \pm 7.9$ years. The time since diagnosis of infection with HIV-1 varied from 3.5 years to 16 years (average $=9.22 \pm 2.81$ years) and the duration of treatment with antiretrovirals varied from 2 to 13 years (average $=7.5 \pm 2.70$ years). In relation to the quantification of HIV-1 viral RNA (viral load), in 31 patients $(51.66 \%)$ it was undetectable.

Of the 79 patients selected for the study who were characterized as non-carriers of lipodystrophy syndrome, 50 (63.29\%) were male and 29 (36.70\%) female; 60 (75.9\%) were Caucasian, 08 (10.1\%) AfroBrazilians and 11 (13.9\%) of mixed race. The length of time since diagnosis with infection by HIV-1 varied from 2 to 20 years (average $=7.37 \pm 4.05$ years) and the duration of antiretroviral treatment from 1.5 to 15 years (average $=5.46 \pm 2.74$ years). In relation to viral load, $47(59.49 \%)$ of the patients presented one which was 
undetectable. The lipidogram values of the patients with and without LS are shown in Table 1.

Table 1 - Lipidogram values of the patients with HIV-1, with and without LS

\begin{tabular}{lcc}
\hline \multicolumn{1}{c}{ Variables } & $\begin{array}{c}\text { With LS } \\
(\mathbf{n}=\mathbf{6 0})\end{array}$ & $\begin{array}{c}\text { Without LS } \\
(\mathbf{n}=\mathbf{7 9})\end{array}$ \\
\hline Cholesterol $(\mathrm{mg} / \mathrm{dL})$ & $199.61 \pm 57.68$ & $160,05 \pm 25,63$ \\
HDL cholesterol $(\mathrm{mg} / \mathrm{dL})$ & $38.3 \pm 12.54$ & $41.21 \pm 11.01$ \\
LDL cholesterol $(\mathrm{mg} / \mathrm{dL})$ & $113.47 \pm 49.54$ & $96.54 \pm 22.52$ \\
Triglycerides $(\mathrm{mg} / \mathrm{dL})$ & $303.1 \pm 256.57$ & $100.76 \pm 34.87$ \\
\hline
\end{tabular}

Reference values: Total cholesterol: < $200 \mathrm{mg} / \mathrm{dL}$; HDL: >35 mg/dL; LDL: $<130 \mathrm{mg} / \mathrm{dL}$; Triglycerides: < $150 \mathrm{mg} / \mathrm{dL}$.

Regarding morphological abnormalities, 23 patients (38.33\%) showed signs of lipoatrophy, 9 (15\%) only showed signs of fat accumulation and 28 patients (46.66\%) presented the mixed form. The stratifications, in accordance to the abnormalities' localization on the body, are presented in Table 2 .

Table 2 - LS morphological abnormalities' localization, according to body region

\begin{tabular}{|c|c|c|}
\hline Variables & $n=60$ & $\%$ \\
\hline \multicolumn{3}{|l|}{ Lipoatrophy } \\
\hline Face & 15 & 25.0 \\
\hline Face, UL & 1 & 1.6 \\
\hline Face, LL & 1 & 1.6 \\
\hline Face, UL, LL & 5 & 8.3 \\
\hline UL, LL & 1 & 1.6 \\
\hline \multicolumn{3}{|l|}{ Lipohypertrophy } \\
\hline Abdomen & 5 & 8.3 \\
\hline Abdomen, breast & 2 & 3.3 \\
\hline Abdomen, dorsocervical & 1 & 1.6 \\
\hline Abdomen, thorax & 1 & 1.6 \\
\hline \multicolumn{3}{|l|}{ Mixed form } \\
\hline Face, breast & 1 & 1.6 \\
\hline Face, dorsocervical & 1 & 1.6 \\
\hline Abdomen, UL, LL & 3 & 5.0 \\
\hline Abdomen, UL, buttocks, breast & 1 & 1.6 \\
\hline Abdomen, buttocks, prominent veins & 1 & 1.6 \\
\hline Abdomem, face & 4 & 6.6 \\
\hline Abdomen, face, dorsocervical & 1 & 1.6 \\
\hline Abdomen, face, UL & 2 & 3.3 \\
\hline Abdomen, face, UL, LL & 6 & 10.0 \\
\hline Abdomen, face, UL, LL, prominent veins & 1 & 1.6 \\
\hline Abdomen, face, UL, LL, dorsocervical & 1 & 1.6 \\
\hline Abdomen, face, buttocks & 1 & 1.6 \\
\hline Abdomen, face, buttocks, prominent veins & 1 & 1.6 \\
\hline Abdomen, face, buttocks, UL, LL & 2 & 3.3 \\
\hline Abdomen, face, buttocks, UL, LL, dorsocervical & 1 & 1.6 \\
\hline $\begin{array}{l}\text { Abdomen, face, buttocks, UL, LL, prominent } \\
\text { veins, breast }\end{array}$ & 1 & 1.6 \\
\hline
\end{tabular}

UL: upper limbs; LL: lower limbs.
In the analysis of the most-affected body regions, the researchers verified the therapeutic regimens used. Table 3 shows the comparison of the therapeutic regimens most used by the patients with and without LS. Table 4 shows the comparison of each retroviral medication used by the patients with and without LS.

Table 3 - Comparison of the therapeutic regimens most used by the patients with and without LS

\begin{tabular}{lccc}
\hline \multicolumn{1}{c}{ Therapeutic regimen } & $\begin{array}{c}\text { With LS } \\
(\mathbf{n}=\mathbf{1 8})\end{array}$ & $\begin{array}{c}\text { Without LS } \\
(\mathbf{n}=\mathbf{5 8})\end{array}$ & $\boldsymbol{P}$ \\
\hline AZT, 3TC, EFZ & 05 & 36 & $\mathbf{0 . 0 1 4 9}$ \\
AZT, 3TC, NVP & 02 & 06 & 1.0000 \\
TDF, 3TC, NVP & 02 & 0 & 0.0537 \\
TDF, 3TC, EFZ, LPV/r & 02 & 01 & 0.1378 \\
D4T, 3TC, EFZ & 04 & 03 & 0.0502 \\
AZT, 3TC, LPV/r & 01 & 02 & 0.5611 \\
AZT, 3TC, RTV, ATV & 0 & 02 & 1.0000 \\
AZT, 3TC, NFV & 0 & 03 & 1.0000 \\
TDF, 3TC, RTV, ATV & 01 & 03 & 1.0000 \\
TDF, 3TC, LPV/r & 01 & 02 & 0.5611 \\
\hline
\end{tabular}

Nucleoside Analog Reverse Transcriptase Inhibitors (NARTI): AZT: Zidovudine; d4T: Stavudine; 3TC: Lamivudine; TDF: Tenofovir. Non-nucleoside reverse transcriptase inhibitor (NNRTI): EFZ: Efavirenz; NVP: Nevirapine.

Protease inhibitor (PI): ATV: Atazanavir; NFV: Nelfinavir; RTV: Ritonavir; LPV/r: (Lopinavir/Ritonavir).

Statistically-significant data is in bold type.

Table 4 - Comparison of the action of each retroviral medication used by patients with and without LS

\begin{tabular}{lccc}
\hline Antiretroviral & $\begin{array}{c}\text { With LS } \\
(\mathbf{n}=\mathbf{6 0})\end{array}$ & $\begin{array}{c}\text { Without LS } \\
(\mathbf{n}=\mathbf{7 9})\end{array}$ & $\boldsymbol{P}$ \\
\hline AZT & 23 & 58 & $<\mathbf{0 . 0 0 0 1}$ \\
$3 T C$ & 47 & 74 & $\mathbf{0 . 0 1 0 3}$ \\
TDF & 19 & 13 & $\mathbf{0 . 0 4 2 7}$ \\
d4T & 17 & 11 & 0.0536 \\
ddI & 10 & 04 & $\mathbf{0 . 0 4 3 2}$ \\
ABC & 02 & 0 & 0.1845 \\
NVP & 06 & 10 & 0.7899 \\
EFV & 34 & 46 & 0.8643 \\
LPV/r & 14 & 10 & 0.1160 \\
ATV & 07 & 10 & 1.0000 \\
RTV & 12 & 09 & 0.2314 \\
NFV & 01 & 06 & 0.1402 \\
SQV & 04 & 02 & 0.4025 \\
APV & 02 & 0 & 0.1845 \\
T-20 & 02 & 0 & 0.1845 \\
\hline
\end{tabular}

Nucleoside analog reverse transcriptase inhibitors (NARTI): AZT: Zidovudine; ddI: Didanosine; ABC: Abacavir; d4T: Stavudine; 3TC: Lamivudine; TDF: Tenofovir.

Non-nucleoside reverse transcriptase inhibitor (NNRTI): EFZ: Efavirenz; NVP: Nevirapine.

Protease inhibitor (PI): ATV: Atazanavir; NFV: Nelfinavir; RTV: Ritonavir; SQV: Saquinavir; APV: Amprenavir; LPV/r: (Lopinavir/Ritonavir).

Fusion inhibitor (FI): T- 20: Enfuvirtide.

Statistically-significant data is in bold type. 


\section{Discussion}

The pathogenicity of LS has been under study for over 10 years, and various factors have been identified as contributing to its development, such as gender, age, duration and seriousness of infection with HIV-1 $1^{(2,16)}$, and the use of antiretroviral therapy ${ }^{(1-2)}$, in addition to the influence of the inflammatory cytokine genes in patients with LS on ARVT(17).

Of the alterations caused by LS, those which cause great difficulties for the patients are the alterations in body harmony negatively impacting on their daily activities ${ }^{(11)}$. In our study, the morphological abnormalities were described in 23 patients (38.33\%) in the form of lipoatrophy, in $9(15 \%)$ as signs of fat accumulation, and 28 patients $(46.66 \%)$ in the mixed form. These prevalencies are close to a description which evaluated a sample of 1,348 patients $^{(8)}$.

Lipoatrophy has been showed to be more frequent than lipohypertrophy ${ }^{(18)}$ and the face is the mostaffected body region, followed by the lower limbs, the buttocks, and the upper limbs(18). In the present study's stratification, the face was the most-affected region, although the authors did not identify differences of prevalence between the upper limbs (MMSS) and the lower limbs (MMII), neither lipoatrophy exclusive to the buttocks, which was only perceived in the mixed form of LS. In relation to lipohypertrophy, the abdomen was the most-affected body region, in line with other studies ${ }^{(2,8)}$, followed by the breast, dorsocervical region and thorax. The most found mixed form was shown by the presence of lipohypertrophy of the abdomen and atrophy of the face, upper limbs and lower limbs.

Retroviral drugs' association with LS is incontestable and was described a long time ago. In view of this, an analysis was undertaken of the therapeutic combinations most used by the two groups of patients studied - with and without LS (Table 3). Thus, the therapeutic regimen made up by the combination of Zidovudine + Lamivudine + Efavirenz (AZT + 3TC + EFZ) was shown to be a protector against LS $(p=0.0149)$. A study carried out with 100 patients who received this same therapeutic combination for 48 weeks and who were later evaluated using imaging exams - computerized tomography and DEXA - dual X-ray absorptiometry - confirms that this therapeutic regimen is not associated with significant morphological changes, as it resulted in a minimal and modest fat accumulation ${ }^{(19)}$.

The influence of NARTI class medications in the development of LS is predominantly reported through the use of Stavudine $(d 4 T)^{(20)}$ and of $A Z T$, in lower intensity ${ }^{(21)}$.

When the authors analyzed each antiretroviral drug in isolation (Table 4), two drugs from the NARTI class - AZT and Lamivudine (3TC) - seemed to suggest protection against the development of LS $(p<0.0001$ and $p=0.0103$, respectively). However, the authors emphasize that a better investigation is necessary, including a thorough analysis of the therapeutic combinations used. In addition, consistent information was not found on the influence of 3TC on its own in the development of LS. Furthermore, there is a report of the combination of these two drugs in the development of morphological changes ${ }^{(22)}$.

According to the present study's data, a further two drugs in this class - Tenofovir (TDF) and Didanosine (ddI) seem to contribute to the development of LS ( $p=0.0427$ and $p=0.0432$, respectively). The information on the role of ddI in LS are conflicting: one study states that this drug is independently associated with $\operatorname{LS}^{(23)}$ and another, that the use of ddI is significantly associated with the depletion of mitochondrial DNA in the adipose tissue of patients with peripheral lipoatrophy, and that this may be reverted with discontinuation of use ${ }^{(24)}$. However, another study states that ddI does not contribute to peripheral lipoatrophy ${ }^{(25)}$. In relation to TDF, in contrast to what the present study's authors found, it seems there is a consensus in the literature that the substitution of $\mathrm{d} 4 \mathrm{~T}$ with TDF minimizes the risk of developing $\mathrm{LS}^{(20)}$, improving the recuperation of peripheral adipose tissue and in this way contributing to the reversal of lipoatrophy(26).

Despite the PI class being widely related to $\mathrm{LS}^{(5)}$, the authors did not determine influences of these medications in the present study.

New antiretroviral drugs are being developed and used in the treatment against infection by HIV, and further studies will be necessary on their adverse effects over time. The authors understand that the fact that the study does not determine the exact length of treatment for each type of antiretroviral and/or therapeutic regimen - which can interfere in the development of LS - is a limitation on the study. However, the authors can provide support for specialized nursing care for this client group, in regard to monitor their therapeutic regimens; identifying and intervening in both morphological changes and changes in their lipid profile, and providing psychosocial support in the face of changes in body image. 


\section{Conclusion}

With this study, the authors conclude that the region most affected by lipoatrophy was the face, the region most affected by lipohypertrophy was the abdomen, and the region most affected by the mixed form was a complex of changes present in the abdomen, face, MMSS and MMII. Of the therapeutic regimens most used by the patients (both with and without LS), that composed of $A Z T+3 T C+E F Z$ seemed to protect against the development of LS. However, further studies are necessary, particularly in relation to the drugs AZT, 3TC, TDF and ddI in the development of LS. In relation to nursing care, it is possible to identify the need for knowledge of each drug's effects, so as to achieve early interventions which avoid the changes in body image, as well as the consequences of this. Working in a participative way in the treatment the nurse will help the patient to deal with the difficulties related to self-esteem, as well as contributing to a reduced rate of abandonment of the therapy.

\section{References}

1. Madge S, Kinloch-de-Loes S, Mercey D, Johnson MA, Weller IV. Lipodystrophy in patients naïve to HIV protease inhibitors. AIDS. 1999;13:735-7.

2. Martinez E, Mocroft A, Garcia-Viejo MA, Pérez-Cuevas JB, Blanco JL, Mallolas J, et al. Risk of lipodystrophy in HIV-1-infected patients treated with protease inhibitors: a prospective cohort study. Lancet. 2001;357:592-8.

3. Carr A, Samaras K, Thorisdottir A, Kaufmann GR, Chisholm DJ, Cooper DA. Diagnosis, prediction and natural course of HIV protease inhibitor-associated lipodystrophy, hyperlipidaemia and diabetes mellitus: a cohort study. Lancet. 1999;353(9170):2093-9.

4. Lake JE, Wohl D, Scherzer R, Grunfeld C, Tien PC, Sidney $S$, et al. Regional fat deposition and cardiovascular risk in HIV infection: the FRAM study. AIDS Care. 2011;23(8):929-38.

5. Carr A, Cooper DA. Images in clinical medicine. Lipodystrophy associated with an HIV-protease inhibitor. N Engl J Med. 1998;339(18):1296.

6. Shaw AJ, McLean KA, Evans BA. Disorders of fat distribution in HIV infection. Int J STD AIDS. 1998;9(10):595-9.

7. Carr A, Samaras K, Burton S, Law M, Freund

J, Chisholm DJ, et al. A syndrome of peripheral lipodystrophy, hyperlipidaemia and insulin resistance in patients receiving HIV protease inhibitors. AIDS. $1998 ; 12(7):$ F51-8.
8. Miller J, Carr A, Emery S, Law M, Mallal S, Baker D, et al. HIV lipodystrophy: prevalence, severity and correlates of risk in Australia. HIV Med. 2003;4(3):293-301.

9. Diehl LA, Dias JR, Paes AC, Thomazini MC, Garcia LR, Cinagawa $E$, et al. Prevalence of HIV-associated lipodystrophy in Brazilian outpatients: relation with metabolic syndrome and cardiovascular risk factors. Arq Bras Endocrinol Metabol. 2008;52(4):658-67.

10. Palella FJ Jr, Delaney KM, Moorman AC, Loveless MO, Fuhre J, Satten GA, et al. Declining morbidity and mortality among patients with advanced human immunodeficiency virus infection. HIV Outpatient Study Investigators. N Engl J Med. 1998;338(13):853-60.

11. Blanch J, Rousaud A, Martinez E, De Lazzari E, Milinkovic A, Peri JM, et al. Factors associated with severe impact of lipodystrophy on the quality of life of patients infected with HIV-1. Clin Infect Dis. 2004;38(10): 1464-70.

12. Gomes AMT, Silva EMP, Oliveira DC. Representações sociais da AIDS para pessoas que vivem com HIV e suas interfaces cotidianas. Rev. Latino-Am. Enfermagem [Internet]. maio-jun 2011 [acesso 03 set 2012];19(3):[8 telas]. Disponível em : http://www.scielo.br/pdf/rlae/ v19n3/pt_06.

13. Sanches RS, Mill J, Machado AA, Donadi EA, Morais Fernandes AP. Facial lipoatrophy: appearances are not deceiving. J Assoc Nurses AIDS Care. 2009;20(3):169-75.

14. Reid C, Courtney M. A randomized clinical trial to evaluate the effect of diet on weight loss and coping of people living with HIV and lipodystrophy. J Clin Nurs. 2007;16(7B):197-206.

15. Chiou PY, Kuo BI, Lee MB, Chen YM, Chuang P, Lin LC. A programme of symptom management for improving quality of life and drug adherence in AIDS/HIV patients. J Adv Nurs. 2006;55(2):169-79.

16. Lichtenstein KA, Ward DJ, Moorman AC, Delaney KM, Young B, Palella FJ Jr, et al. Clinical assessment of HIVassociated lipodystrophy in an ambulatory population. AIDS 2001;15(11):1389-98.

17. Castelar L, Silva MM, Castelli EC, Deghaide $\mathbf{N H}$, Mendes-Junior CT, Machado AA, et al. Interleukin-18 and interferon-gamma polymorphisms in Brazilian human immunodeficiency virus-1-infected patients presenting with lipodystrophy syndrome. Tissue Antigens. 2010;76(2):126-30.

18. Cabrero E, Griffa L, Burgos A; HIV Body Physical Changes Study Group. Prevalence and Impact of Body Physical Changes in HIV Patients Treated with Highly Active Antiretroviral Therapy: Results from a Study on 
Patient and Physician Perceptions. AIDS Patient Care STDS. $2010 ; 24(1): 5-13$.

19. Jemsek JG, Arathoon E, Arlotti M, Perez C, Sosa $\mathrm{N}$, Pokrovskiy $\mathrm{V}$, et al. Body fat and other metabolic effects of atazanavir and efavirenz, each administered in combination with zidovudine plus lamivudine, in antiretroviral-naive HIV-infected patients. Clin Infect Dis. 2006;42(2):273-80.

20. Han SH, Zhou J, Saghayam S, Vanar S, Phanuphak $\mathrm{N}$, Chen YM, et al. Prevalence of and risk factors for lipodystrophy among HIV-infected patients receiving combined antiretroviral treatment in the Asia-Pacific region: results from the TREAT Asia HIV Observational Database (TAHOD). Endocrinol J. 2011;58(6):475-84.

21. Mallal SA, John M, Moore CB, James IR, McKinnon EJ. Contribution of nucleoside analogue reverse transcriptase inhibitors to subcutaneous fat wasting in patients with HIV infection. AIDS. 2000;14(10):1309-16.

22. van Vonderen MG, van Agtmael MA, Hassink EA, Milinkovic A, Brinkman K, Geerlings SE, et al. Zidovudine/lamivudine for HIV-1 infection contributes to limb fat loss. PLoS One. 2009;4(5):e5647.

23. Gelenske T, Farias FA, Alencar Ximenes RA, Melo HR, Albuquerque MF, Carvalho EH, et al. Risk factors in human immunodeficiency virus/acquired immunodeficiency syndrome patients undergoing antiretroviral therapy in the state of Pernambuco, Brazil: a case-control study. Metab Syndr Relat Disord. 2010;8(3):271-7.

24. Buffet $M$, Schwarzinger $M$, Amellal $B$, Gourlain $K$, Bui $P$, Prévot $M$, et al. Mitochondrial DNA depletion in adipose tissue of HIV-infected patients with peripheral lipoatrophy. J Clin Virol. 2005;33(1):60-4.

25. Lowe $\mathrm{SH}$, Hassink EA, van Eck-Smit BL, Borleffs JC, Lange JM, Reiss P. Stavudine but not didanosine as part of HAART contributes to peripheral lipoatrophy: a substudy from the Antiretroviral Regimen Evaluation Study (ARES). HIV Clin Trials. 2007;8(5):337-44.

26. Ribera E, Paradiñeiro JC, Curran A, Sauleda S, GarcíaArumí E, Castella $E$, et al. Improvements in subcutaneous fat, lipid profile, and parameters of mitochondrial toxicity in patients with peripheral lipoatrophy when stavudine is switched to tenofovir (LIPOTEST study). HIV Clin Trials. 2008;9(6):407-17. 